ECLETTICA A

www.scielo.br/eq

www.ecletica.iq.unesp.br

Volume 33, número 3, 2008

\title{
Highly sensitive spectrophotometric methods for the determination of olanzapine
}

\author{
H. D. Revanasiddappa* and M. A. Veena \\ Department of Chemistry, University of Mysore, Manasagangothri, Mysore-570 006, India; tel.: +91-821-2419669 \\ *hdrevanasiddappa@yahoo.com
}

\begin{abstract}
Highly sensitive and selective spectrophotometric methods (A and B) were developed for the determination of micro amounts of olanzapine (OLZ). Method A (direct method) is based on the oxidation of olanzapine with a known excess of iodine monochloride (ICl) in an acidic medium. Under the same condition, thymol blue was iodinated by unreacted $\mathrm{ICl}$, and the absorbance of uniodinated thymol blue was measured at $536 \mathrm{~nm}$. The decrease in ICl concentration is a measure of drug concentration. In method B (indirect method), oxidation of OLZ by a known excess of Ce(IV) in sulfuric acid medium followed by the reaction of unreacted Ce(IV) with leuco crystal violet (LCV) to crystal violet $(\mathrm{CV})$, which is measured in an acetate buffer medium ( $\mathrm{pH} 4.9)$ at $580 \mathrm{~nm}$. These methods obey the Beer's law in the concentration range of 0.2-1.6 $\mu \mathrm{g} \mathrm{mL}^{-1}$ (method A) and 0.1-1.4 $\mu \mathrm{g} \mathrm{mL} \mathrm{m}^{-1}(\operatorname{method} \mathrm{B})$. The developed procedures have been successfully applied to the determination of OLZ in pure and in dosage forms. The results exhibit no interference from the presence of excipients. The reliability of the methods was established by parallel determination of OLZ against the reference method.
\end{abstract}

Keywords: Olanzapine; Iodinemonochloride-thymol blue; Ce(IV)-Leuco crystal violet; spectrophotometry; pharmaceutical analysis.

\section{Introduction}

Olanzapine (OLZ), chemically 2-methyl-4[4-methyl-1-piperazinyl]-10H-thieno [2, 3b] [1,5] benzodiazepine, is an antipsychotic agent belongs to the thienobenzodiazepine class and it has been widely used in the treatment of schizophrenia . A facile, selective and sensitive method for OLZ determination is of importance in routine analysis. Various methods have been reported for its assay in pharmaceuticals and in biological samples include, GC [1], HPLC [2-5], UV spectrophotometry [6, 7] and FIA [8]. A few visible spectrophotometric methods $[9,10]$ have been reported for its analysis. The reported methods (except spectrophotometric methods) required expensive experimental set-up. Therefore, a simple, highly sensitive and cost effective method is required for the analysis of OLZ in pure and in dosage forms.

In the present paper, two simple and highly sensitive spectrophotometric methods [A and B] are proposed for the determination of OLZ in pure and in pharmaceutical formulations using iodine monochloride ( $\mathrm{ICl}$ ) -thymol blue (TB), and $\mathrm{Ce}(\mathrm{IV})-\mathrm{LCV}$ reagent systems.

\section{Experimental \\ Apparatus}

All absorbance measurements were made 
with ANALYTIC JENA AG model SPECORD50 and SYSTRONICS-166 spectrophotometers with $1 \mathrm{~cm}$ matched quartz cells.

An Elico model IL- 610 digital pH meter was used for $\mathrm{pH}$ measurements.

\section{Reagents}

All chemicals used were of analytical reagent grade, and distilled water was used throughout the study.

Iodine monochloride (ICl) $\left[2.25 \times 10^{-4} \mathrm{~mol}\right.$ $\left.L^{-1}\right]$ : Prepared by dissolving $0.28 \mathrm{~g} \mathrm{KI}, 0.18 \mathrm{~g}$ $\mathrm{KIO}_{3}$ and $50 \mathrm{~g} \mathrm{NaCl}$ in $400 \mathrm{~mL}$ water. The solution was cooled, diluted to $500 \mathrm{~mL}$ with water and standardized iodometrically. The concentration of prepared $\mathrm{ICl}$ solution was found to be $0.0047 \mathrm{~mol} \mathrm{~L}^{-1}$ in $2.25 \mathrm{~mol} \mathrm{~L}^{-1} \mathrm{H}_{2} \mathrm{SO}_{4}$. A $4.8 \mathrm{~mL}$ aliquot of prepared stock solution was diluted to $100 \mathrm{~mL}$ with $2.25 \mathrm{~mol} \mathrm{~L}^{-1} \mathrm{H}_{2} \mathrm{SO}_{4}$ to get $2.25 \times 10^{-4}$ mol L-1 ICl solution.

Thymol blue (TB) $\left[0.015 \mathrm{~mol} \mathrm{~L}^{-1}\right]$ : It was prepared by dissolving $0.01 \mathrm{~g}$ of TB in $100 \mathrm{~mL}$ of $0.1 \mathrm{~mol} \mathrm{~L}^{-1} \mathrm{NaOH}$

$\mathrm{Ce}(\mathrm{IV})$ [ $1000 \mu \mathrm{g} \mathrm{mL}^{-1}$ : It was prepared by dissolving $0.3913 \mathrm{~g}$ ammonium ceric nitrate in $100 \mathrm{~mL}$ distilled water containing $0.5 \mathrm{~mL}$ of conc. $\mathrm{HNO}_{3}$

Leuco Crystal Violet (LCV) [0.025\% $(\mathrm{m} / \mathrm{v})$ ]: Prepared by adding $0.25 \mathrm{~g} \mathrm{LCV}, 200 \mathrm{~mL}$ distilled water and $3.0 \mathrm{~mL}$ of $85.0 \%(\mathrm{~m} / \mathrm{v})$ phosphoric acid to a 1.0 liter volumetric flask and shaken gently until the dye dissolved. The contents of the flask were diluted to the mark with distilled water.

Acetate buffer [ $p H$ 4.9]: Prepared by dissolving $13.6 \mathrm{~g}$ of sodium acetate trihydrate in 80 $\mathrm{mL}$ distilled water. Solution $\mathrm{pH}$ was adjusted to 4.9 with acetic acid, and the mixture was diluted to $100 \mathrm{~mL}$ with water.

Others: Aqueous solutions of $\mathrm{NaOH}[0.1$ mol L-1 $]$ and $\mathrm{H}_{2} \mathrm{SO}_{4}$ [2.25 $\mathrm{mol} \mathrm{L}^{-1}$ and $0.25 \mathrm{~mol} \mathrm{~L}^{-}$ 1] were used.

\section{Standard solution}

Aqueous solution of olanzapine (OLZ) was prepared by dissolving the required amount of the sample in distilled water. A working standard solution was prepared by a suitable dilution of standard solution.

\section{Standard procedures}

\section{Method A}

An aliquot of the solution containing 0.2-1.6 $\mu \mathrm{g} \mathrm{mL}^{-1}$ of OLZ was transferred into a series of 10.0 $\mathrm{mL}$ calibrated flasks. Then, a volume of $2.5 \mathrm{~mL}$ of $2.25 \times 10-4 \mathrm{~mol} \mathrm{~L}^{-1} \mathrm{ICl}$ was added to each flask. After $10.0 \mathrm{~min}, 1.5 \mathrm{~mL}$ of $0.01 \%(\mathrm{~m} / \mathrm{v}) \mathrm{TB}$ was added and the contents were diluted to the mark with distilled water. The absorbance of the dye was measured after 5.0 min against water at $536 \mathrm{~nm}$.

\section{Method B}

An aliquot of the solution containing 0.1-1.4 $\mu \mathrm{g} \mathrm{mL} L^{-1}$ of OLZ was transferred into a series of 10.0 $\mathrm{mL}$ calibrated flasks. Then, volumes of $0.5 \mathrm{~mL}$ each of the Ce(IV) [ $\left.50.0 \mu \mathrm{g} \mathrm{mL}^{-1}\right]$ and $0.025 \%(\mathrm{~m} / \mathrm{v})$ LCV were added. The reaction mixture was kept in a water bath $\left(\sim 55.0^{\circ} \mathrm{C}\right)$ for $5.0 \mathrm{~min}$; after being cooled to room temperature $\left(26 \pm 2{ }^{\circ} \mathrm{C}\right)$, the contents were diluted to the mark with acetate buffer of $\mathrm{pH}$ 4.9 and mixed well. The blank was prepared similarly omitting the OLZ and its absorbance was measured against distilled water at $580 \mathrm{~nm}$. The decrease in absorbance corresponding to consumed Ce(IV) and in turn, to OLZ concentration was obtained by subtracting the absorbance of OLZ solution from that of the blank. The calibration graph was drawn by plotting the difference in absorbance against the concentration of OLZ, and the amount of OLZ was computed from the calibration curve.

\section{Tablets}

Twenty tablets of olanzapine (OLZ) were weighed and ground into a fine powder. An accurately weighed powder equivalent to $100 \mathrm{mg}$ of the active component was transferred into a $100 \mathrm{~mL}$ calibrated flask and dissolved in distilled water and the mixture was shaken thoroughly for $30 \mathrm{~min}$. Then it was diluted to the mark with distilled water, mixed well and filtered using quantitative filter paper. An aliquot of this solution was diluted appropriately to obtain the working concentrations and analyzed as described under standard procedures.

\section{Results and discussion}

In an acidic condition, a known excess of $\mathrm{ICl}$ is used to oxidize $\mathrm{SO}_{2}$ and the unreacted $\mathrm{ICl}$ 
is used to iodinates thymol blue. The decrease in $\mathrm{ICl}$ concentration is a measure of the $\mathrm{SO}_{2}$ concentration. The absorbance of uniodinated thymol blue is measured at $536 \mathrm{~nm}$. This reaction has been the basis of the best method for the determination of $\mathrm{SO}_{2}$ in environmental samples [11]. In this work, a known excess of $\mathrm{ICl}$ is used to oxidize olanzapine to colorless sulfoxide [9] in an acidic condition. In the same condition, the unreacted $\mathrm{ICl}$ is used to iodinates TB, thereby a decrease in $\mathrm{ICl}$ concentration is directly proportional to the drug concentration. This formed the basis of OLZ determination in method A.

When TB is iodinated completely with $\mathrm{ICl}$, the absorbance at $536 \mathrm{~nm}$ decreases and reaches a minimum value. With an increase in OLZ concentration, there is a concomitant fall in $\mathrm{ICl}$ concentration, and as a result less iodinated TB is formed. The difference in concentration of uniodinated thymol blue in the reaction mixture gives the exact concentration of the drug. The absorption spectra [Fig.1] show that, a linear increase in absorbance with increasing drug concentration.

In order to establish the linear range, various experimental parameters such as acid, concentration of $\mathrm{ICl}$ and concentration of TB were optimized, and the optimum conditions were specified in the recommended procedure. The acidity of $\mathrm{ICl}$ solution can vary from $1.5 \mathrm{~mol} \mathrm{~L}^{-1}$ to $3.0 \mathrm{~mol} \mathrm{~L}^{-1}$ in $\mathrm{H}_{2} \mathrm{SO}_{4}$,

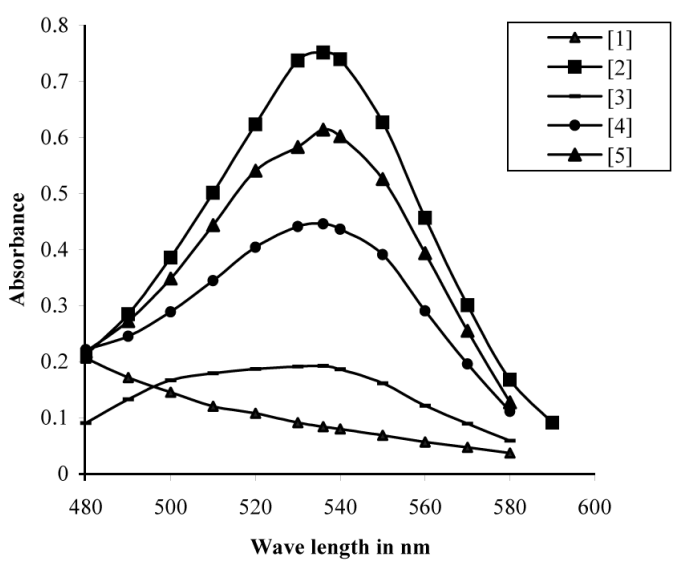

Figure 1. Absorption spectra of the [1] $1.5 \mathrm{~mL}$ TB $+2.5 \mathrm{~mL} \mathrm{ICl}$ [2] $1.5 \mathrm{~mL}$ TB (Without ICl) [3] 0.4 $\mu \mathrm{g} \mathrm{mL} \mathrm{L}^{-1}$ [4] $1.0 \mu \mathrm{g} \mathrm{mL}^{-1}$ [5] $1.4 \mu \mathrm{g} \mathrm{mL}^{-1}$ OLZ measured against water. and an overall acidity of $2.25 \mathrm{~mol} \mathrm{~L}^{-1} \mathrm{ICl}$ (working standard) was taken for subsequent studies.

The concentration of TB required under optimum acidic condition to produce an absorbance of 0.752 at $536 \mathrm{~nm}$ was selected. Volumes of 1.5 $\mathrm{mL} \mathrm{TB}$ in presence of $2.5 \mathrm{~mL}$ of $2.25 \mathrm{~mol} \mathrm{~L}^{-1} \mathrm{H}_{2} \mathrm{SO}_{4}$ in a total volume of $10 \mathrm{~mL}$ were used, and the corresponding $\mathrm{ICl}$ concentration required to decrease the absorbance to 0.084 was fixed by using $2.25 \times 10^{-4} \mathrm{~mol} \mathrm{~L}^{-1} \mathrm{ICl}$ in $2.25 \mathrm{~mol} \mathrm{~L}^{-1} \mathrm{H}_{2} \mathrm{SO}_{4}$ in a final volume of $10 \mathrm{~mL}$. Thus, the optimum conditions were included in experimental procedure. Hence, volumes of $2.5 \mathrm{~mL}$ of $2.25 ? 10-4 \mathrm{~mol} \mathrm{~L}^{-1} \mathrm{ICl}$ and $1.5 \mathrm{~mL}$ of $0.01 \%(\mathrm{~m} / \mathrm{v})$ TB were used.

The constant absorbance values were observed $5 \mathrm{~min}$ after the dilution. Therefore, a reaction time of 5 min was fixed before the absorbance measurements. The color system was found to be stable for $>12 \mathrm{~h}$.. The reaction time was not affected in-between the temperatures 5 and $60{ }^{\circ} \mathrm{C}$, beyond this, there is a decrease in the absorbance values.

In an acid solution, Ce(IV) oxidize LCV to violet colored crystal violet, which shows maximum absorption at $580 \mathrm{~nm}$. In this method [method B], a known excess of Ce(IV) [ $3.0 \mu \mathrm{g}$ $\mathrm{mL}^{-1}$ ] was utilized to oxidize OLZ in sulfuric acid medium to colorless sulfoxide form. The unreacted $\mathrm{Ce}(\mathrm{IV})$ was determined by reacting it with LCV to CV in an acetate buffer medium (pH 4.9). This reaction formed the basis for the determination of micro amounts of OLZ in method B.

Preliminary experiment was performed to fix the linear range (Beer's law curve) for Ce(IV) with the use of LCV under the optimum experimental conditions. The concentration range of $\mathrm{Ce}(\mathrm{IV})$ was found to be $0.0-2.8 \mu \mathrm{g} \mathrm{mL}^{-1}$. Thus, a known excess of cerium(IV) [ ie., $3.0 \mu \mathrm{g} \mathrm{mL}^{-1}$ ] solution was selected for further experiment.

Olanzapine, when added in increasing amounts, proportionately consume $\mathrm{Ce}(\mathrm{IV})$; consequently there is a concomitant fall in the concentration of $\mathrm{Ce}(\mathrm{IV})$. This is observed as a proportional decrease in the absorbance of the reaction mixture on increasing the concentration of OLZ [Fig.2].

The various acids (sulfuric, hydrochloric and phosphoric acids) were studied, sulfuric acid was found to be the best acid for the system. The constant absorbance readings were obtained in the range $0.25-1.5 \mathrm{~mL}$ of $0.25 \mathrm{~mol} \mathrm{~L}^{-1} \mathrm{H}_{2} \mathrm{SO}_{4}$ at a tem- 


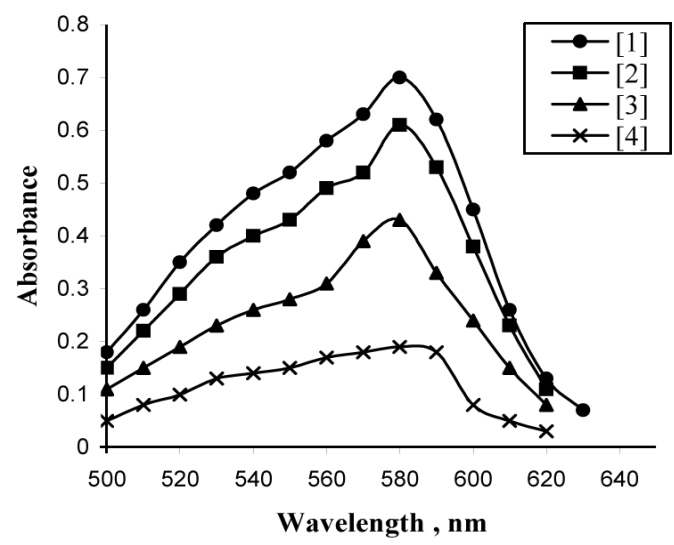

Figure 2. Absorption spectra of the [1] Blank (without OLZ) [2] $0.2 \mu \mathrm{g} \mathrm{mL}^{-1}$ [3] $0.6 \mu \mathrm{g} \mathrm{mL}^{-1}$ [4] $1.2 \mu \mathrm{g}$ $\mathrm{mL}^{-1} \mathrm{OLZ}$ measured against water.

perature $\sim 55^{\circ} \mathrm{C}$ for $5.0 \mathrm{~min}$, out side this range of acidity, the absorbance values was decreased. Thus, a volume of $0.5 \mathrm{~mL}$ of $0.25 \mathrm{~mol} \mathrm{~L}^{-1} \mathrm{H}_{2} \mathrm{SO}_{4}$ in a total volume of $10.0 \mathrm{~mL}$ reaction mixture was used in all subsequent work. At room temperature $\left(26 \pm 2{ }^{\circ} \mathrm{C}\right)$, the oxidation of LCV to CV is slow. Thus, a tem- perature of $\sim 55^{\circ} \mathrm{C}(5.0 \mathrm{~min})$ was maintained for the complete color development.

The optimum concentration of LCV leading to maximum color stability was found to be $0.5 \mathrm{~mL}$ of $0.025 \%(\mathrm{~m} / \mathrm{v})$ reagent per $10.0 \mathrm{~mL}$ of the reaction mixture. The formed dye was stable in a buffer of $\mathrm{pH} 4.9$ and hence acetate buffer of pH 4.9 was used as a diluent.

\section{Analytical data}

Optical characteristics such as Beer's law

Table 1. Optical characteristics and precision data.

\begin{tabular}{lcc}
\hline Parameter & $\mathrm{A}$ & $\mathrm{B}$ \\
\hline Beer's law limit $\left(\mu \mathrm{g} \mathrm{mL}^{-1}\right)$ & $0.2-1.6$ & $0.1-1.4$ \\
Molar absorptivity $\left(\mathrm{L} \mathrm{mol}^{-1} \mathrm{~cm}^{-2}\right)$ & $1.41 \times 10^{5}$ & $1.43 \times 10^{5}$ \\
Sandell's sensitivity $\left(\mu \mathrm{g} \mathrm{cm}^{-2}\right)$ & 0.0022 & 0.0031 \\
Correlation coefficient $[\mathrm{r}]$ & 0.9999 & 0.9999 \\
Slope [b] & 0.4219 & 0.4052 \\
Intercept [a] & 0.0163 & 0.0198 \\
Detection limit [DL] $\left(\mu \mathrm{g} \mathrm{mL}^{-1}\right)$ & 0.0218 & 0.0149 \\
Quantitation limit [QL] $\left(\mu \mathrm{g} \mathrm{mL}^{-1}\right)$ & 0.0661 & 0.0454 \\
\hline
\end{tabular}

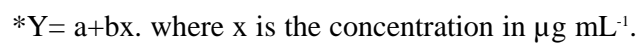

Table 2. Results of assay of olanzapine in dosage forms.

\begin{tabular}{|c|c|c|c|c|c|c|c|c|}
\hline \multirow[b]{2}{*}{ 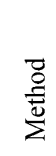 } & \multirow{2}{*}{ 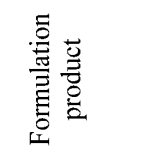 } & \multicolumn{2}{|r|}{ Proposed } & \multirow{2}{*}{$\begin{array}{l}\text { Method } \\
\% \operatorname{Rec} \pm \mathrm{SD}\end{array}$} & \multirow{2}{*}{$\frac{\text { Reference }}{\% \mathrm{C} \mathrm{V}}$} & \multirow{2}{*}{$\frac{\text { Method [9] }}{\% \operatorname{Rec} \pm \text { S D }}$} & \multirow[b]{2}{*}{ t-value ${ }^{b}$} & \multirow[b]{2}{*}{ F-value } \\
\hline & & $\begin{array}{c}\text { Amount } \\
\text { taken } \\
\left(\mu \mathrm{g} \mathrm{mL} L^{-1}\right)\end{array}$ & $\begin{array}{l}\text { Amount } \\
\text { found } \\
\left(\mu \mathrm{g} \mathrm{mL} L^{-1}\right)\end{array}$ & & & & & \\
\hline \multirow{10}{*}{ A } & & 0.6 & 0.59 & $99.6 \pm 0.20$ & 0.33 & $100.1 \pm 0.16$ & 1.34 & 1.56 \\
\hline & Oleanz & 1.0 & 1.00 & $100.3 \pm 0.46$ & 0.45 & $99.5 \pm 0.29$ & 0.83 & 2.51 \\
\hline & $5.0 \mathrm{mg} / \mathrm{tab}$ & 1.4 & 1.39 & $99.1 \pm 0.14$ & 0.10 & $100.8 \pm 0.31$ & 0.63 & 4.90 \\
\hline & & 0.6 & 0.60 & $100.1 \pm 0.42$ & 0.69 & $99.5 \pm 0.51$ & 1.63 & 2.10 \\
\hline & Olexar & 1.0 & 0.99 & $99.9 \pm 0.28$ & 0.28 & $100.2 \pm 0.17$ & 1.01 & 2.71 \\
\hline & $5.0 \mathrm{mg} / \mathrm{tab}$ & 1.4 & 1.39 & $99.5 \pm 0.36$ & 0.21 & $99.6 \pm 0.21$ & 1.86 & 2.93 \\
\hline & & 0.6 & 0.59 & $98.1 \pm 0.17$ & 0.39 & $102.0 \pm 0.20$ & 1.70 & 1.38 \\
\hline & Oliza & 1.0 & 0.99 & $98.9 \pm 0.41$ & 0.41 & $99.2 \pm 0.28$ & 1.08 & 2.14 \\
\hline & $7.5 \mathrm{mg} / \mathrm{tab}$ & 1.4 & 1.39 & $99.9 \pm 0.23$ & 0.16 & $100.4 \pm 0.43$ & 2.00 & 3.49 \\
\hline & & 0.4 & 0.40 & $101.2 \pm 0.18$ & 0.44 & $99.8 \pm 0.31$ & 0.86 & 2.96 \\
\hline \multirow{8}{*}{ B } & Oleanz & 0.8 & 0.79 & $99.8 \pm 0.26$ & 0.32 & $100.9 \pm 0.41$ & 1.97 & 3.44 \\
\hline & $5.0 \mathrm{mg} / \mathrm{tab}$ & 1.2 & 1.21 & $100.8 \pm 0.48$ & 0.40 & $99.5 \pm 0.25$ & 0.70 & 3.68 \\
\hline & & 0.4 & 0.39 & $99.2 \pm 0.23$ & 0.58 & $99.9 \pm 0.18$ & 1.14 & 1.63 \\
\hline & Olexar & 0.8 & 0.80 & $100.5 \pm 0.51$ & 0.63 & $101.5 \pm 0.33$ & 1.36 & 2.38 \\
\hline & $5.0 \mathrm{mg} / \mathrm{tab}$ & 1.2 & 1.19 & $99.5 \pm 0.37$ & 0.31 & $100.2 \pm 0.21$ & 1.21 & 3.10 \\
\hline & & 0.4 & 0.39 & $99.7 \pm 0.14$ & 0.32 & $99.6 \pm 0.23$ & 1.60 & 2.69 \\
\hline & Oliza & 0.8 & 0.78 & $98.6 \pm 0.40$ & 0.50 & $99.9 \pm 0.19$ & 0.95 & 4.43 \\
\hline & $7.5 \mathrm{mg} / \mathrm{tab}$ & 1.2 & 1.20 & $100.5 \pm 0.23$ & 0.19 & $100.1 \pm 0.50$ & 1.17 & 4.72 \\
\hline
\end{tabular}

${ }^{\mathrm{a}}$ Average of five determinations, ${ }^{\mathrm{b}}$ Tabulated value $2.78,{ }^{\mathrm{c}}$ Tabulated value 6.39 . 
range, molar absorptivity, Sandell's sensitivity, slope, intercept, detection and quantitation limits of both the methods are presented in table 1 .

\section{Applications to pharmaceuticals}

The proposed methods were applied to the quantitative determination of OLZ in pharmaceutical preparations and the results are presented in Table 2. A statistical analysis of the results by Students $t$ and F-tests showed no significant difference in accuracy and precision between the proposed and reference methods [9].

The interference with commonly associated excipients such as talc, starch, glucose, gum acacia, sodium alginate and magnesium stearate was investigated by preparing different synthetic mixtures containing about 20-30 mg of pure drug and 3-5 fold excess amounts of the excipients and performing recovery studies using the developed methods, and recoveries obtained were in the range $99.6-100.8 \%$

\section{Conclusions}

The methods developed for the determination of OLZ are simple, selective and offer the advantages of high sensitivity without the need for extraction. The proposed reagents are easily available and cost-effective, and these methods do not involve any stringent reaction conditions, and non-interference from associated substances in the dosage forms. The methods developed have been utilized to determine OLZ in pure as well as in pharmaceutical samples.

\section{Acknowledgments}

One of the authors [M.A.V] is thankful to the University of Mysore, Mysore for providing the necessary facilities.

Received June 092008

Accepted August 182008

\section{References}

[1] A. A. Elian, Forensic Sci. International. 91 (1998) 231. [2] S.Vinay, Z. Zahid, Farooqui, Mazhar, Asian J.Chem. 18 (2006) 1212.

[3] M. A. Ragi, G. Casamenti, R.Mandrioli, G.Izzo, E. Kenndler, J. Pharm. Biomed. Anal. 23 (2000) 973.

[4] D.W.Boulton, J. S. Markowitz, C. L. De Vane, J.Chromatogr. B 759 (2001) 319.

[5] A.Berna, B. Ackermann, K.Ruterbories,S.Glass, J. Chromatogr. B. 767 (2003) 163.

[6] F.S.Aman, T. Nisa, Alim-um, J.Chem.Society of Pakistan. 27 (2005) 163.

[7] D.G.Sankar,m J.M.Rajendra Kumar, M.V.V.N. Reddy, J. Inst. Chemists (India) 75 (2003) 135.

[8] A. Jasinska, E. Nalewajko, Anal.Chim.Acta. 508 (2003) 165.

[9] A. Krebs, B. Starczewska, H. Puzanowska-Tarasiewicz, J. Sledz, Anal.Sci. 22 (2006) 829.

[10] K.V.Shiva Prasad, J. M.Rajendra Kumar, M.V.V.N. Reddy, G. Prabhakar, D. G. Sankar, Asian J. Chem.15 (2003) 1127.

[11] N. Gayathri, N. Balasubramanian, J. Assoc.Off. Anal.Chem.International. 84 (2001) 1068 
